\title{
Day-night activity rhythm of the cold seep shrimp Alvinocaris stactophila (Caridea: Alvinocarididae) from the Gulf of Mexico
}

\author{
Jacopo Aguzzi*s, Eva Ramirez-Llodra*†, Guy Telesnicki ${ }^{\ddagger}$ and Mercedes Camps* \\ *Institut de Ciències del Mar (CSIC), Passeig Marítim de la Barceloneta 37-49, 08003 Barcelona, Spain. `National \\ Oceanography Centre, Southampton, European Way, SO14 3ZH, Southampton, UK. Penn State University-Department of

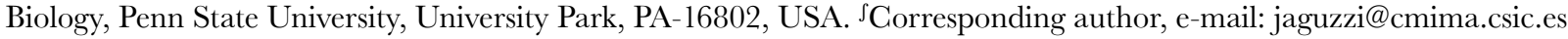

The activity rhythm of the cold seep shrimp Alvinocaris stactophila from the Gulf of Mexico slope $650 \mathrm{~m}$ depth) was investigated in the laboratory in relation to an artificial $12 \mathrm{~h}$ light-dark regime. Animals were sampled with a submersible and transferred into individual aquaria where their activity was monitored for 5 $\mathrm{d}$ by taking digital video snapshots every $30 \mathrm{~s}$. An observer analysed the footage by counting the number of times an animal crossed two perpendicular lines drawn on a PC screen per 30 min interval. Resulting time series were represented over consecutive days and the waveform analysis was used to precisely assess the phase (i.e. the peak timing) and its limits (i.e. onset and offset) in relation to light ON and OFF. The majority (73\%) of animals showed a marked nocturnal pattern of activity with number of movements close to zero during the photophase. Waveform analysis showed that the behavioural transition from activity to inactivity after light ON occurred within approximately $1 \mathrm{~h}$. Considering the general lack of knowledge on the regulation of activity rhythms of crustaceans from subtidal areas, the present data provide a new insight on the role played by light in the regulation of animal activity rhythm in deep-water environments such as those of the cold seeps in the Gulf of Mexico.

\section{INTRODUCTION}

Cold seeps are characterized by the seepage of fluids and a high concentration of methane and sulphides in the sediment (Sibuet \& Olu, 1998). Their faunal communities are sustained by the primary production of chemoautotrophic microorganisms that use these reduced chemicals as a source of energy (Tunnicliffe et al., 2003). A large amount of data concerning seep faunal communities in terms of biodiversity, species richness and distribution has been obtained during studies carried out in the Gulf of Mexico over the past decade (Sibuet \& Olu, 1998; MacDonald et al., 2003; Cordes et al., 2005). For these areas, the trophic structure and life cycles of some species have been described as well (Tyler \& Young, 1999; MacAvoy et al., 2002, 2005).

The deep-sea shrimp Alvinocaris stactophila Williams, 1988 represents an interesting species of the cold seep community. To date, its presence has been reported only on the cold seep areas of the upper and lower Louisiana slopes and the Florida Escarpment. The species lives over the mussel beds and vestimentiferan bushes (Bergquist et al., 2003; Cordes et al., 2005; Komai \& Segonzac, 2005; Martin \& Haney, 2005). Recently, Copley \& Young (2006) reported a seasonal pattern in its reproductive cycle in contrast with the hypothesized decrease in the seasonality of biological cycles of marine invertebrates over bathymetry (Orton, 1920). Although this seems true for many deep-sea species, there are notable exceptions, such as in the case of deepsea pandalids (Company et al., 2003), abyssal echinoderms
(Tyler et al., 1982, 1994) or some seep and vent species (reviewed in Tyler \& Young, 1999).

In the marine deep-water environment the day-night cycle is one of the most important time cues (i.e. zeitgebers) responsible for synchronization (i.e. entrainment) of organisms' biological rhythms (e.g. Naylor, 2005). The entrainment relies on the presence of a pacemaker (Aschoff, 1981) but to date, this has been poorly studied in deep-water marine crustaceans because of the technical constraints of animal sampling and maintenance in the laboratory. The entrainment of daily cycles in behaviour and physiology to different photoperiod lengths is of importance for marine organisms in order to regulate growth, reproduction and behaviour according to seasons (Naylor, 2005).

Seasonal patterns in the biological cycles of deep-water species have been related to peaks in primary production at the superficial layers of the water column. These peaks apparently provide the organic input sustaining the metabolism of the gametogenesis (Ecklebarger \& Walting, 1995) or supply food for the larval phase, increasing the survival rate of the dispersing offspring (Gage \& Tyler, 1991; Tyler et al., 1994). To our knowledge, no direct measurement of light intensity is available from the cold-seep habitats in the Gulf of Mexico. Therefore, an effect of the photoperiod length and light intensity as modulators of animal reproduction can not be discounted. The entrainment of the biological clock at a diel base may represent the mechanism that synchronizes the reproduction to diel variations in the duration of the photophase (i.e. photoperiodism). 


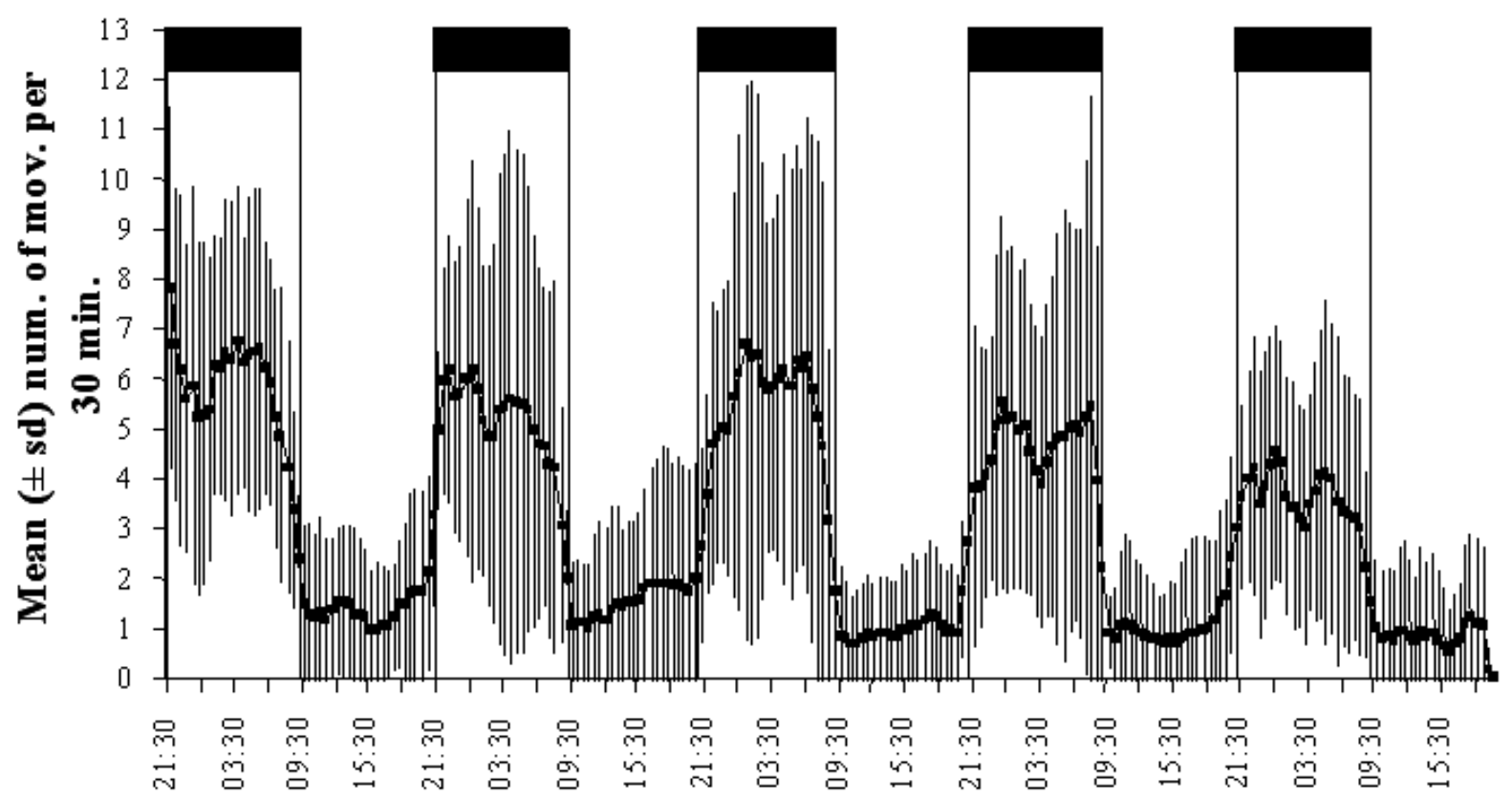

\section{Time of the experiment (h)}

Figure 1. The consensus curve reporting the locomotor activity of Alvinocaris stactophila as computed by averaging $( \pm \mathrm{SD})$ values of activity of all time series $(\mathrm{N}=8)$ per corresponding $30 \mathrm{~min}$ interval. The reported pattern indicates a consistent increase of locomotor activity in darkness phases (i.e. the boxes with black bars on top). Conversely a marked reduction of activity is reported during the day. Peak maxima present high interindividual variability.

The aim of this study is to characterize the presence of a behavioural rhythm in A. stactophila in relation to the day-night cycle. Data on the diel regulation of activity are interesting not only for the deep-sea context in which this dynamic occurs but also to explain the mechanism controlling the reported seasonality (i.e. photoperiodism) in its reproduction.

\section{MATERIALS AND METHODS}

Shrimp were collected as an associated fauna of the seep mussel Bathymodiolus childressi from the Gulf of Mexico Brine Pool NR-1 site $\left(27^{\circ} 43^{\prime} 24^{\prime \prime N} 91^{\circ} 16^{\prime} 24^{\prime \prime} \mathrm{W}\right)$, on the Louisiana slope, at a depth of $650 \mathrm{~m}$ (MacDonald et al., 1990), using the hydraulic scoop of the Johnson Sea Link submersible (Harbor Branch Oceanographic Institution). Specimens were recovered in an insulated box mounted to the front of the submersible. Upon surfacing, healthy specimens were immediately placed in an aerated $8^{\circ} \mathrm{C}$ seawater tank. Approximately $25 \%$ of the seawater volume in the tank was replaced every $48 \mathrm{~h}$ for the duration of the cruise.

Healthy specimens were shipped to the Pennsylvania State University and housed in an aquarium system designed primarily for the long-term maintenance of $B$. childressi. That system consisted of three connected tanks filled with $370 \mathrm{l}$ of artificial seawater (Reef Crystals, Aquarium Systems). It was hosted in an environmental growth chamber at $5^{\circ} \mathrm{C}$. A 200-1 main tank contained the shrimp and 20-30 mussels. This was equipped with a protein skimmer, an aeration system and several inches of coral rubble substrate. An adjacent 801 tank was used for bio-filtration. This was filled with plastic media balls (Pentair Aquatics, Bio-Mate) and illuminated with a 175 watt metal halide bulb (Coralife 5500K Ultra) placed directly above the tank. A third sealed and vented tank acted as a bubbling chamber for periodic addition of methane to the system. A timer-driven solenoid plumbed between the tank and a compressed gas cylinder bubbled technical grade methane (98\% pure) through the chamber for seven minute periods, eight times per day. Circulation among tanks was maintained with a flow through canister pump (Eheim 2215). With the exception of methane this system required no exogenous input and healthy specimens of shrimp, mussels as well as other endemic seep fauna, including gastropods, galatheid crabs, and polychaetes, have been successfully maintained for several years.

Ambient indirect illumination of the specimen tank from the adjacent biofiltration tank was continuous prior to the experiment. The shrimp were not exposed to any other light or diurnal cues except for brief periods of overhead fluorescent lighting during occasional tank maintenance and weekly 40-1 water changes. The population of $A$. stactophila maintained in this aquarium presented good health conditions, with normal locomotion and even being reproductively active as shown by mature females carrying eggs (E. Ramirez-Llodra, personal observation).

The experiment was performed with healthy adult shrimp $(\mathrm{N}=11)$ showing good activity conditions (4 males and 7 females). At the beginning of the test these were moved into individual aquaria of $28 \times 13 \times 18 \mathrm{~cm}$ (length, height and depth respectively) and placed on 3 rows in a cold room at a temperature of $5^{\circ} \mathrm{C}$. During 5 days, animals were exposed to a 12-h light-darkness cycle of 100 lux, created with a 


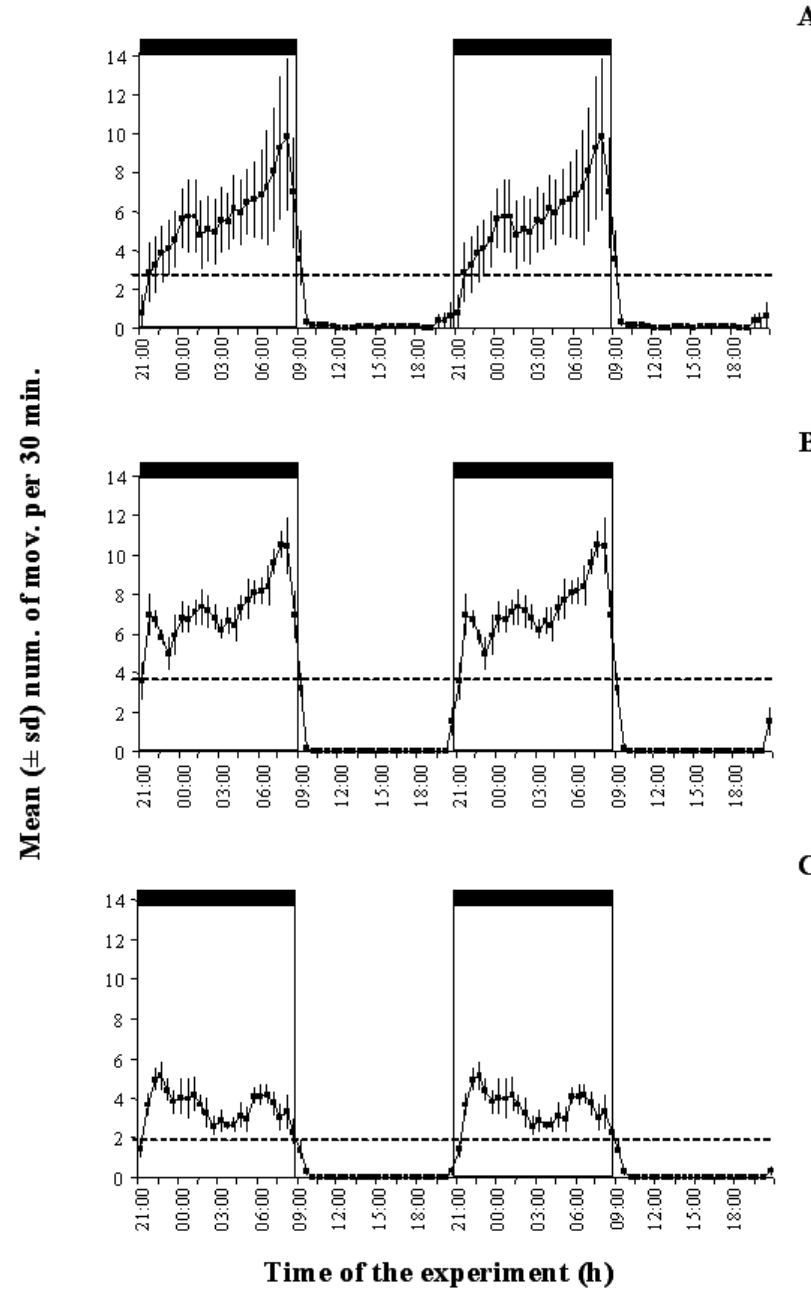

Figure 2. Waveform analysis on time series of number of movements per 30 min of three individuals $(\mathrm{A}, \mathrm{B}, \mathrm{C})$ of Alvinocaris stactophila are presented as an example for reported interindividual variability. The mesor (horizontal dashed line) defines the timing of significant increase at light $\mathrm{OFF}$ and decrease at light $\mathrm{ON}$ of behavioural activity with respect to the scotophase (i.e. the boxes with black bars on top).

white light neon lamp. That high light intensity was chosen to enhance the response of animals to the photic phase and to compact their behavioural swimming bouts into single coherent outputs avoiding at the same time the insurgence of ultradian rhythms (Aguzzi et al., 2006a). Light ON and OFF timings were respectively set at 0900 and $2100 \mathrm{~h}$.

A digital video camera, connected to a MAC laptop was used to film all aquaria simultaneously. The software iStopMotion (Boinx Software) was used to capture frames every $30 \mathrm{~s}$ (time lapse mode). An observer used QuickTime to quantify the walking and swimming activity of each shrimp. According to Aguzzi et al. (2004) a cross was drawn on the computer's screen over each aquarium to quantify both the horizontal and vertical movements of shrimp per 30 min interval.

Resulting time-series of activity data were represented over consecutive days with respect to the day-night cycle by counting the number of movements per $30 \mathrm{~min}$. The phasing of activity rhythms with respect to timings of light
ON and OFF was evaluated by waveform analysis. Time series were cut into $24 \mathrm{~h}$ segments and values were averaged per corresponding time intervals of $30 \mathrm{~min}$. The resulting values $( \pm \mathrm{SD})$ were represented over $24 \mathrm{~h}$ constituting the waveform. Waveforms were double-plotted to better visualize the periodicity in time series of data with respect to the daynight cycle. A mesor (midline estimating statistic of rhythm) was computed by averaging all mean values of the waveform as detailed by Hammond \& Naylor (1977). Values above the mesor represent the significant increase in the activity (i.e. the peak). Peak limits at light $\mathrm{ON}$ and $\mathrm{OFF}$ were identified by the first value above and the last value below the mesor, respectively.

For each waveform showing a discernible rhythmic pattern, a value of amplitude was computed as max-min. Mean $( \pm \mathrm{SD})$ amplitude in the activity rhythm of Alvinocaris was given by averaging all amplitudes of rhythmic waveforms.

\section{RESULTS}

Marked behavioural rhythms were recorded in 8 animals (73\%). Only 3 individuals showed unclear activity patterns, with peaks presenting a disruption into sub-components of difficult attribution to a particular phase of the light darkness regime. These individuals were those located into tanks at the periphery of our field of observation and this made difficult the recording of their activity under the darkness phase. As a consequence, these individuals were omitted from the successive analyses.

The representation of time series under the form of a consensus curve over consecutive day-night cycles of $24 \mathrm{~h}$ is presented in Figure 1. A marked nocturnal activity with minimum of movements during the photophase is evident. Data are consistent in all animals since clear peaks and troughs are visible despite the wide amplitude of standard deviations. The variability in time series of data was provoked by animals with differential activity during consecutive darkness phases (i.e. scotophases).

Waveform analysis (Figure 2) for the time series presented in Figure 1 confirms the presence of a defined phase of activity at darkness as well as a marked transition of activity levels at timing of light $\mathrm{ON}$ and OFF. The time series show a marked interindividual variability with peaks of different amplitude at the scotophase. The mean locomotor rate was equal to $8.0 \pm 3.0$ movements per $30 \mathrm{~min}$, with absolute minima of 0 movements and absolute maxima of 20 movements per 30 min during the photophase and the scotophase, respectively.

The time interval required by all rhythmic animals to significantly increase their activity (i.e. values above the mesor) at light OFF was of $86 \pm 19 \mathrm{~min}$. This time interval was bigger than the one required by animals to reduce their activity at light $\mathrm{ON}(64 \pm 34 \mathrm{~min})$.

\section{DISCUSSION}

In the present study a marked behavioural rhythm was reported for Alvinocaris stactophila in relation to an imposed 12 $\mathrm{h}$ light-darkness regime. This species showed an increase in the rate of behavioural activity at night time pointing toward its nocturnal habit in the field. Conversely, the activity was 
suppressed during the photophase. Considering the general lack of knowledge on the regulation of diel activity rhythms of deep-water invertebrates (Naylor, 2005), the present data open interesting questions about the role played by light as a modulator of animal behaviour in the environment of the Brine Pool cold seeps of the Gulf of Mexico. The present data are of importance for the determination of a role played by light in the modulation of the behavioural activity of a benthic organism dwelling close to the aphotic zone. Up to date, few studies exist on the rhythmic regulation of the behaviour of such deep-water organisms, and data of this kind open new perspectives for studies on the structuring of marine communities down to $1000 \mathrm{~m}$ with respect to the light intensity (Waterrman, 2001).

The eyes of $A$. stactophila are fully developed, but other species of the same genus present different degeneration levels of the eye depending on their ecology (e.g. Gaten et al, 1998; Jinks et al., 1998). The evolutionary destiny of deepsea decapod eyes can be independent from the regulation of activity rhythms upon photoperiod cycles (Gaten et al, 1998). Decapod species possess extra-retinal input pathways involved in the circadian photoreception(Cronin, 1986). The entrainment of behavioural rhythms to photoperiod cycles may occur via non visual-forming systems in environments where light, although scant, is still present (e.g. Sandeman et al., 1990; Fanjul-Moles et al., 2003, 2004). A similar dynamic is observed in demersal deep-sea fish where very few light quanta can activate pineal photoreceptors (Priede et al., 1999).

In marine ecosystems, light penetration varies as function of depth with an efficiency that is dependent upon season given the primary production (Jerlov, 1968). Its intensity and spectral quality represent one of the most powerful environmental agents determining the probability of species habitat occupation (Waterrman, 2001). Species performing extensive diel vertical migrations use variation in the intensity of blue (480 nm) light to modulate their behavioural pattern upon the day-night cycle (Frank \& Widder, 1997, 2002; Naylor, 2006). To our knowledge, there are no available data on light penetration into the cold seep environment of the upper Louisiana slope. The Brine Pool and adjacent cold seep areas on the Louisiana slope underlie a region of high surface productivity, with a marked seasonality and peak production in the winter months (Müller-Karger et al., 1991). This surface production sinks to the seafloor and could cause seasonal variations in water turbidity. However, the lack of precise light measurements at the cold seep habitat itself does not clarify if the faunal communities are exposed to any light cycles of appreciable intensity.

For example, in the more turbid water of the western Mediterranean, light intensity at 400-430 $\mathrm{m}$ reaches values of $9.16 \times 10^{-8} \mu \mathrm{E}_{i} \mathrm{~m}^{-2} \mathrm{~s}^{-1}$ at midday in June, and under this photic condition local benthic decapods display marked diel behavioural cycles as in the case of the burrowing lobster Nephrops norvegicus (Linnaeus, 1758) (Aguzzi et al., 2003) and the burying prawns Solenocera membranacea (Risso, 1816) (Aguzzi et al., 2006b). Diel variations in the intensity of blue light $(480 \mathrm{~nm})$, the only radiation reaching almost $1000 \mathrm{~m}$ depth (Herring, 2003), drive animals to emerge from the sediment at daytime (Aguzzi et al., 2003,
2006). Interestingly, for $\mathcal{N}$. norvegicus such rhythmicity is endogenously controlled (e.g. Atkinson \& Naylor, 1976). Its relationship with the day-night cycle is kept down to 600 $\mathrm{m}$ into the north-east Atlantic, where animals still show a maximum in emergence toward midday (Cristo \& Castro, 2005). Such a depth range is close to the one of Alvinocaris analysed in this study.

Alvinocaris stactophila responds to the presence of light by inhibiting its locomotion and swimming behaviours. The inhibition of movement at photophases may represent an exigency of concealment that is typically recorded in marine environmental contexts where visual-predators are active (De Robertis, 2002). Animals may be exposed to visual predators if crawling on the mussel bed during daytime. Although the body of $A$. stactophila is almost transparent, a means often used by small decapods to reduce animal visibility to predators, their presence can be likely detected by movement (Warrant \& Locket, 2004). Little is known about the predators of $A$. stactophila, but cold-seep shrimp populations could be targeted by benthopelagic fish, whose presence increases at the seabed during daylight phases (Suetsugu \& Ohta, 2005).

The annual variation in the day/night length is used in shallow water species to time their seasonal rhythms such as, for example, synchronous reproduction (Ramirez-Llodra, 2002). In the deep sea, most species have continuous or semi-continuous reproductive patterns, but investigations in the last decade have shown that seasonal reproduction is also present (reviewed in Young, 2003). However, the precise environmental cues used by these species to time their seasonal rhythms are unknown. In cold seeps, seasonal reproductive cycles have been described for a number of species, such as A. stactophila (Copley \& Young, 2006), the clam Calyptogena kilmeri (Lisin et al., 1997) and the mussel Bathymodilus childressi from the Gulf of Mexico (Tyler et al., 2007). Authors suggest that seasonal reproduction is related to seasonal peaks of phytodetritus in the water column, which can be used as a source of energy by the dispersing larvae and enhancing their survival potential (Lisin et al., 1997; Copley \& Young, 2006; Tyler et al., 2007).

The existence of a common mechanism controlling the behaviour at a diel base and growth and reproduction at seasonal scale, through the measurement of the photoperiod length duration (i.e. photoperiodism), is currently under discussion (reviewed in Saunders, 2002; Dunlap et al., 2004). The present data are therefore of interest since the occurrence of a marked diel activity rhythm may be considered as a marker for the presence of the endogenous control of those seasonal rhythms observed in the reproductive patterns of cold-seep animals. Animals may entrain their reproductive cycle to peaks in primary production of above water column layer, based on the diel modulation of their activity cycle (i.e. measurement of the scotophase length). Similarly to $A$. stactophila, which presents a combination of diel and seasonal rhythms (present data and Copley \& Young, 2006), other cold-seep invertebrates may show a diel regulation in their behaviour and future experimental work using live specimens is essential to understand the ecology of these species and the environmental forcing conditions to observed biological patterns. 
The experimental work of this study was supported by a Fondation Total Grant to E. Ramirez-Llodra and P. Tyler under the ChEss-Census of Marine Life Program. E. Ramirez-Llodra and M. Camps were supported by the ChEss-Census of Marine Life programme. J. Aguzzi is a Juan de la Cierva (MEC, Spain) posdoctoral fellow. G. Telesnicki was supported by the US NSF, the Minerals Management Service and The Penn State University. The authors would like to thank Charles R. Fisher at The Penn State University for laboratory and specimen availability and for comments and advice during the study. A special acknowledgement is also devoted to J.B. Company and F. Sardà for their advice. Specimen collection and maintenance were funded by multiple grants from the US NSF, the Mineral Management Service and the National Oceanic and Atmospheric Administration to C.R. Fisher.

\section{REFERENCES}

Aguzzi, J., Chiesa, J.J., Caprioli, R., Cascione, D., Magnifico, G., Rimatori, V. \& Costa C., 2006a. Preliminary evidences of circadian fan activity rhythm in Sabella spallanzanii (Gmelin, 1791) (Polychaeta: Sabellidae). Scientia Marina, 70, 727-734.

Aguzzi, J., Company, J.B. \& Abelló, P., 2004. Locomotor activity of continental slope Nephrops norvegicus (Decapoda: Nephropidae). Journal of Crustacean Biology, 24, 282-290.

Aguzzi, J., Company,J.B. \& Abelló, P., 2006b. Rhythmic behaviour of the burying prawn Solenocera membranacea (Decapoda: Penaeoidea: Solenoceridae) in the western Mediterranean: a perspective through depth and season. Bulletin of Marine Sciences, 79, 353-364.

Aguzzi, J., Sardà, F., Abelló, P., Company, J.B. \& Rotllant, G., 2003. Diel and seasonal patterns of Nephrops norvegicus (Decapoda: Nephropidae) catchability in the western Mediterranean. Marine Ecology Progress Series, 258, 201-211.

Aschoff, J., 1981. Free-running and entrained circadian rhythms. In Handbook of behavioral neurobiology (ed. J. Aschoff), Vol. 4, pp. 81-93. New York: Plenum Press.

Atkinson, R.J.A. \& Naylor, E., 1976. An endogenous activity rhythm and the rhythmicity of catches of Nephrops norvegicus (L.). Journal of Experimental Marine Biology and Ecology, 25, 95-108.

Bergquist, D.C. et al., 2003. Community structure of vestimentiferan-generated habitat islands from Gulf of Mexico cold seeps. Fournal of Experimental Marine Biology and Ecology, 289, 197-222.

Company, J.B., Sardà, F., Puig, P., Cartes, J.E. \& Palanques, A., 2003. Duration and timing of reproduction in decapod crustaceans of the NW Mediterranean continental margin: is there a general pattern? Marine Ecology Progress Series, 261, 201216.

Copley, J.T.P \& Young, C.M., 2006. Seasonality and zonation in the reproductive biology and population structure of the shrimp Alvinocaris stactophila (Caridea: Alvinocarididae) at a Louisiana slope cold seep. Marine Ecology Progress Series, 315, 199-209.

Cordes, E., Hourdez, H., Predmore, B., Redding, M. \& Fisher, C., 2005. Succession of hydrocarbon seep communities associated with the long-lived foundation species Lamellibrachia luymesi. Marine Ecology Progress Series, 305, 17-29.

Cristo, M. \& Castro, M., 2005. Field estimation of daily ration of Norway lobster (Nephrops norvegicus) in the south of Portugal. New Zealand Fournal of Marine and Freshwater Research, 39, 485-491.

Cronin, T.W. 1986. Photoreception in marine invertebrates. American Zoologist, 26, 403-415.

De Robertis, A., 2002. Size-dependent visual predation risk and the timing of vertical migration: an optimized model. Limnology and Oceanography, 47, 925-933.

Dunlap, J.C., Loros, J.J. \& DeCursey, P., 2004. Chronobiology: biological timekeeping. Sunderland, MA: Sinauer Associates.
Eckelbarger, K.J. \& Walting, L., 1995. Role of phylogenetic constrains in determining the reproductive patterns in deep-sea invertebrates. Invertebrate Biology, 114, 256-269.

Fanjul-Moles, M.L., Escamilla-Chimal, E.G., Gloria-Soria, A. \& Hernandez-Herrera, G., 2004. The crayfish Procambarus clarkii CRY shows daily and circadian variation. Fournal of Experimental Biology, 207, 1453-1460.

Fanjul-Moles, M.L. \& Prieto-Sagredo, J., 2003. The circadian system of crayfish: a developmental approach. Microscopy Research and Technique, 60, 291-301.

Frank, T.M. \& Widder, E.A., 1997. The correlation of downwelling irradiance and staggered vertical migration patterns of zooplankton in Wilkinson basin, Gulf of Maine. Fournal of Plankton Research, 19, 1975-1991.

Frank, T.M. \& Widder, E.A., 2002. Effects of a decrease in downwelling irradiance on the daytime vertical distribution patterns of zooplankton and micronekton. Marine Biology, 140, 1181-1193.

Gage, J.D. \& Tyler, P.A., 1991. Deep-sea biology. A natural history of organisms at the deep-sea floor. Cambridge: Cambridge University Press.

Gaten, E., Herring, P., Shelton, P. \& Johnson, M., 1998. The development and the evolution of the eyes of vent shrimp (Decapoda: Bresiliidae). Cahiers de Biologie Marine, 39, 287-290.

Hammond, R.D. \& Naylor, E., 1977. Effects of dusk and dawn on locomotor activity rhythms in the Norway lobster Nephrops norvegicus. Marine Biology, 39, 253-260.

Herring, P., 2003. The biology of the deep ocean. Biology of habitats. New York: Oxford University Press.

Jerlov, N.G., 1968. Optical Oceanography. Amsterdam: Elsevier.

Jinks, R., Battelle, B., Herzog, E.D. \& Kass, L., 1998. Sensory adaptation in hydrothermal vent shrimp from the Mid-Atlantic Ridge. Cahiers de Biologie Marine, 39, 309-312.

Komai, T. \& Segonzac, M., 2005. A revision of the genus Alvinocaris Williams and Chace (Crustacea: Decapoda: Caridea: Alvinocarididae), with descriptions of a new genus and new species of Alvinocaris. Fournal of Natural History, 39, 1111-1175.

Lisin, S.E., Hannan, E.E., Kockevar, R.E., Harrold, C. \& Barry, J.P., 1997. Temporal variation in gametogenic cycles of vesicomyd clams. Invertebrate Reproduction and Development, 31, 307-318.

MacAvoy, S.E., Macko, S.A. \& Joye, S.B., 2002. Fatty acid carbon isotope signatures in chemosynthetic mussels and tube worms from Gulf of Mexico hydrocarbon seep communities. Chemical Geology, 185, 1-8.

MacAvoy, S.E., Fisher, C.R., Carney, R.S. \& Macko, S.A., 2005. Nutritional associations among fauna at hydrocarbon seep communities in the Gulf of Mexico. Marine Ecology Progress Series, 292, 51-60.

MacDonald, I.R., Reilly, J.F., Guinasso, N.L., Brooks, J.M., Carney, R.S., Bryant, W.A. \& Bright, T.J., 1990. Chemosynthetic mussels at a brine-filled pockmark in the northern Gulf of Mexico. Science, New York, 248, 1096-1099.

MacDonald, I.R., Sager, W.W. \& Peccini, M.B., 2003. Gas hydrate and chemosynthetic biota in mounded bathymetry at mid-slope hydrocarbon seeps: northern Gulf of Mexico. Marine Geology, 198, $133-158$.

Martin, J.W. \& Haney, T.A., 2005. Deep crustaceans from hydrothermal vents and cold seeps: a review through 2005. Zoological Fournal of the Linnaean Society, 145, 445-522.

Müller-Karger, F.E., Walsh, J.J., Evans, R.H. \& Meyers, M.B., 1991. On the seasonal phytoplankton concentration and sea surface temperature cycles of the Gulf of Mexico as determined by satellites. Fournal of Geophysical Research, 96, $12645-12665$.

Naylor, E., 2005. Chronobiology: implications for marine resources exploitation and management. Scientia Marina, 69 (Suppl.1), 157167. 
Naylor, E., 2006. Orientation and navigation in coastal and estuarine zooplankton. Marine and Freshwater Behaviour and Physiology, 39, 13-24.

Orton, J.H., 1920. Sea temperature, breeding and distribution in marine animals. Fournal of the Marine Biological Association of the United Kingdom, 12, 339-366.

Priede, I.G. et al., 1999. Implication of the visual system in the regulation of activity cycles in the absence of solar light: 2$\left[{ }^{125} \Gamma\right]$ iodomelatonin binding sites and melatonin receptor gene expression in the brains of demersal deep-sea gadiform fish. Proceedings of the Royal Society of London, 266, 2295-2302.

Ramirez-Llodra, E., 2002. Fecundity and life-history strategies in marine invertebrates. Advances in Marine Biology, 43, 88-170.

Sandeman, D.G., Sandeman, R.E. \& de Couet, H.G., 1990. Extraretinal photoreceptors in the brain of the crayfish Cherax destructor. Fournal of Neurobiology, 21, 619-629.

Saunders, D.S., 2002. Insect clocks. Amsterdam: Elsevier.

Sibuet, M. \& Olu, K., 1998. Biogeography, biodiversity and fluid dependence of deep-sea cold-seep communities at active and passive margins. Deep-Sea Research II, 45, 517-567.

Suetsugu, K. \& Ohta, S., 2005. Day and nighttime changes in species composition of deep-sea demersal fishes. Fournal of Oceanography, 61, 187-196.

Tunnicliffe, V., Juniper, K.S. \& Sibuet, M., 2003. Reducing environments of the deep-sea floor. In Ecosystems of the World. Ecosystems of the deep oceans (ed. P.A. Tyler), pp. 81-110. London: Elsevier.
Tyler, P.A., Grant, A., Pain, S.L. \& Gage, J.D., 1982. Is annual reproduction in deep-sea echinoderms a response to variability in their environment? Nature, London, 300, 747-750.

Tyler, P.A., Campos-Creasy, L.S. \& Giles, L.A., 1994. Environmental control of quasi-continuous and seasonal reproduction in deep-sea benthic invertebrates. In Reproduction, larval biology and recruitment of the deep-sea benthos (ed. C.M. Young and K.J. Eckelbarger), pp. 158-178. New York: Columbia University Press.

Tyler, P.A. \& Young, C.M., 1999. Reproduction and dispersal at vents and cold seeps. Fournal of the Marine Biological Association of the United Kingdom, 79, 193-208.

Tyler, P.A., Young, C.M., Dolan, E., Arellano, S.M., Brooke, S.D. \& Baker, M.C., 2007. Gametogenic periodicity in the chemosynthetic cold mussel Bathymodiolus childressi. Marine Biology, 150, 829-840.

Warrant, E.J. \& Locket, N.A., 2004. Vision in the deep sea. Biological Review, 79, 671-712.

Waterrman, T., 2001. Evolutionary challenges of extreme environments (Part 2). Fournal of Experimental Zoology, 291, 130168.

Submitted 26 February 2007. Accepted 26 July 2007. 